$\star$ Rhizomes: Cultural Studies in Emerging Knowledge: Issue 34 (2018)

\title{
Robert Musil, Postmodernism, and the Problem of Subjectification
}

\author{
Brook Montgomery Blair \\ University of Northern Colorado
}

\begin{abstract}
Foucault, Deleuze, and Negri have variously posed the dual problem of selfconstitution and subjectification in highly innovative ways, postmodernists in general have long overlooked the manner in which this problem was earlier developed by one of their most important, if largely unacknowledged, precursors: the great Austrian novelist and essayist Robert Musil (1880-1942). In a series of treatments replete with bold intimations of the radical thought of the 1960s, Musil's literary endeavor was directed, throughout nearly the entirety of his writings, towards ends very similar to the postmodernists, particularly in his elaboration of "essayism" and his accompanying concepts of the "ratioid" and the "nonratioid." Musil's literary project thus serves not merely as an anticipation of the postmodernist gambit but also as an essential complement to it, not least insofar as his endeavors likewise sought to grasp the dual projects of self-constitution and subjectification as simultaneously engaging both power and knowledge while also endeavoring to establish a considerable degree of relative independence from them. As such, Musil's writings may well be situated in the vein of Nietzschean "centauric literature," a type of writing that extends beyond the confines of traditional genres in constituting whatever it might potentially mean to be a human subject in an age that has increasingly outstripped the historical legacies of humanism.
\end{abstract}

I

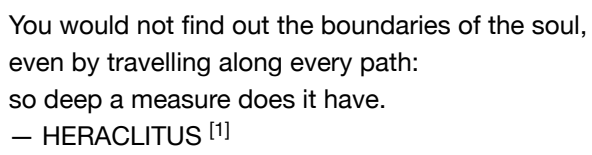

By 'ungrounding' we should understand the freedom of the non-mediated ground, the discovery of a ground behind every other ground, the relation between the groundless and the ungrounded, the immediate reflection of the formless and superior form which constitutes the eternal return.

- DELEUZE, Difference and Repetition [2]

One of the most salient and enduring features of the anti-foundational turn of postmodern thought consists in having occasioned a critical appropriation of the history of philosophy. For the postmodernists, as is well known, the period surrounding 1968 precipitated a virtually seismic reworking of a supposed line of continuity extending all the way from the distant origins of what Leo Strauss was wont to designate as "the Great Tradition" [3] of Plato, Aristotle, and Augustine down to the twentieth century and what Antonio Negri once characterized as the "Geisteswissenschaften and their tradition (Enlightenment and Hegelianism)." ${ }^{[4]}$ In one of his most concise, if also sweeping, statements on the subject, Gilles Deleuze would carry this line of thought to its most extraordinary lengths, proclaiming that "[p]hilosophic discourse is born out of the imperial state, and it passes through 
innumerable metamorphoses."[5] For the postmodernists then, the task of thought would henceforth become one of "not continuing on by way of an interiority, whether this be called the inner soul of consciousness or the inner essence of the concept."[6]

With this overturning of the world of representation, an untamed world of simulacra would emerge in full and clamorous splendor, ${ }^{[7]}$ in turn requiring a new series of mediators ${ }^{[8]}$ pressed in the service of philosophical experimentation. Running counter to the imperial tradition of philosophy, this new series of mediators would increasingly appear in ever sharper relief as this burgeoning philosophical counter-movement began to enter their names in its register: Heraclitus, Lucretius, Spinoza, and, of course, Nietzsche were all eventually cast in pivotal roles - to say nothing of a stunningly rehabilitated Marx. Together, along with a growing host of others, ${ }^{[9]}$ these figures brought in their wake a new and fulgurating ontology, wildly robust and decidedly generative; a dynamic play of forces in perpetual movement, with neither beginning (arche) nor end (telos), in the process constituting nothing less than a materialist metaphysics ${ }^{[10]}$ of pure immanence ${ }^{[11]}$ and the power of the virtual (potentia). ${ }^{[12]}$

If the emergence of this new ontology immediately offered a palpable opening in the traditional schemata of representation, the reinsertion of human activity into this reconceptualization of nature was replete with its own inherent risks and opportunities, as each of the most prominent postmodernist thinkers would, in one way or another, immediately realize. To put matters simply, if there was no longer any stable a priori model on which to base the human essence, the only possibility for self-constitution would lie in a creative process of selection and the introduction of varying degrees of stratification according to one's own tastes and potencies, ${ }^{[13]}$ especially as set forth in Deleuze's great philosophical "chaodyssey [chao-errance]" of "discovering, inventing, new possibilities of life." ${ }^{[14]}$ With the emptying out of representation, ${ }^{[15]}$ that is, of the grounding interiority of either the inner soul of consciousness or the inner essence of the concept, the groundless ground ${ }^{[16]}$ of being could hardly help but, ipso facto, to expose a subjectless subject, ${ }^{[17]}$ bareheaded $^{[18]}$ and forevermore imperiled by the imminent prospect of collapse or terminal implosion ${ }^{[19]}$ while also finding itself almost breathlessly open to a vast array of new possibilities. ${ }^{[20]}$ Resplendent as it was from the very outset, this new materialist metaphysics (explicit as it was in the writings of Deleuze and Negri, and implicit in those of Foucault ${ }^{[21]}$ ) thus presented an altogether new field of problematization for philosophy and life itself.

It is therefore hardly accidental that Keith Ansell Pearson should have depicted Pierre Klossowski's seminal work, Nietzsche and the Vicious Circle, as having portrayed its subject's philosophical project as a "superior existentialism,"[22] for the authentic act of self-constitution must inevitably teeter on the edge of self-dissolution, [23] the risk of collapse and implosion being merely the stakes of the great Nietzschean Welt-Spiel (world-game) ${ }^{[24]}$ of becoming. In the same breath, however, we must recall that, as a result of its inhering in nature itself, perhaps the greatest achievement of human subjectivity as such consequently consists in its capacity for transmutation, transvaluation, or what Félix Guattari once defined as "processes of the realization of autonomy,"[25] of "autopoiesis."[26] In one of his many interviews concerning Michel Foucault, we find a passage, remarkable for both its concision and precision, in which Deleuze renders this capacity as follows:

It's a question 'doubling' the play of forces, of a self-relation that allows us to resist, to elude power, to turn life or death against power. This, according to Foucault, is something the Greeks invented...it's a matter of optional rules that make existence a work of art, rules at once ethical and aesthetic that constitute ways of existing or styles of life (including even suicide). It's what Nietzsche discovered as the will to power operating artistically, inventing 'new possibilities of life.' One should, for all sorts of reasons, avoid all talk of a return to the subject, because these processes of subjectification vary enormously from one period to another and operate through vary disparate rules. What increases their variability is that power (pouvoir) is always taking over any new process and subordinating it to the play of forces, although it can always then recover by inventing new ways of existing, and this can go on indefinitely. So there's no return to the Greeks, either. A process of subjectification, that is the production of a way of existing, can't be equated with a subject, unless we divest the subject of any interiority and even any identity. Subjectification isn't even anything to do with a 'person': it's a specific or collective individuation relating to an event (a time of day, a river, a wind, a life...). It's a mode of intensity, not a personal subject. It's a specific dimension without which we can't go beyond knowledge or resist power (pouvoir). ${ }^{27]}$ 
The later Foucault would become famous (and, in certain circles, infamous) for this treatment of the doubling selfrelation of subjectification, which in essence forms the ethical counterpart to postmodernist ontology; but just as he was hardly alone among his contemporaries in the development of this problématique, it is important to note that, as Kirk, Raven, and Schofield remind us in their extremely useful presentation of Heraclitus, this notion of the human being as embedded, or inhering, within the elemental logos is hardly new: "The soul is composed of fire... The soul-fire is related to the world-fire."[28] To this end, too, we find similar utterances among numerous other figures key to this critical inversion of the imperial tradition of philosophy: Marcus Aurelius conceived it as the spermatikos logos, Lucretius as alma Venus, Spinoza as natura naturans (as opposed to natura naturata), Marx as species-being, and Nietzsche as the will to power (in conjunction with the eternal return, the overman, and ultimately, in his final writings, the transvaluation of values).

As we read in Lucretius, moreover, this generative nature is no less effective in human activity than it is in nature itself, "[f]or every creature feels the purposes for which he can use the power that lies in him [sentit enim vim quisque suam quod possit abuti]. [29] For each of these thinkers, in fact, human activity can only be conceived within this broader frame of self-producing nature, the elemental substrate that Deleuze, both on his own and in tandem with Guattari, would variously characterize as desiring-production, the body without organs, the plane of immanence, or plane of consistency, ${ }^{[30]}$ while Negri would term it, somewhat more simply, constitutive or constituent power (natura naturans). Regardless of each of the many minor, if not insignificant, variations occurring from one figure or concept to the next, we may rest assured that this elemental form-giving power subsists, in Kylie Message's rendering of Deleuze and Guattari's classic formulation, ${ }^{[31]}$ as "a non-formed, non-organised, nonstratified, or destratified body or term," [32] whose power mounts continually from the clamorous multiplicity of the depths (the base or core) ${ }^{[33]}$ rather than allowing itself to be deduced from the supposition of any cognizable unity of the transcendent ${ }^{[34]}$-as Deleuze puts it in The Logic of Sense, this substrate comprises nothing less than the "pure unformed," [35] which is why, mimicking Plato, he elsewhere says "that materialists, if at all intelligent, should speak of power rather than of bodies." [36]

II

Scholarship, art, and philosophy are growing together inside me to such an extent that one day l'm bound to give birth to centaurs...

- NIETZSCHE, Letter to Erwin Rohde, from Basel, late-January and mid-February, 1870 [37]

Might it not be true that, within the framework of an integrated existence (Whatever that might be), knowledge of the world and self-expression belong close together-closer, in any case, than they are usually found under modern-day conditions? Has not the division of the labor of talent that characterized our times led to the tendential opposition of the psychic attitudes that capacitate scientifically oriented knowledge to the expression of the self, while those that accommodate self-expression betray a propensity that is hostile to knowledge? Are not the cults of science and aesthetics the prototypical "complementary idiots" of modernity?

- SLOTERDIJK, The Thinker on Stage: Nietzsche's Materialism, "Centauric Literature" [38]

We do not have too much intellect and too little soul, but too little intellect in matters of the soul.

- MUSIL, "Helpless Europe: A Digressive Journey" [39]

As already suggested, this proposed line of minoritarian thinkers-composed principally of Heraclitus, Lucretius, Spinoza, and Nietzsche-is by no means exhaustive, but each of these figures has by now become so integral to the postmodern philosophical project that it would seem all but impossible to conceive the anti-foundational gambit of inverted Platonism ${ }^{[40]}$ with any philosophical rigor or integrity in their absence. Their texts are as subtle 
as they are thoroughgoing, and their various rejections of traditional schemata of representation are as cogent and principled as those found in their postmodern heirs who came of age in the period surrounding 1968. Despite all the myriad influences at work in the shaping of such thinkers as Deleuze, Foucault, and Negri, it could well be argued that these four predecessors remain inescapable staples when reckoning with the most essential preconditions of their thought. Yet it is in this very setting that I would like to add one more name to this line, a figure of immense importance to these invaluable discussions regarding the relationship between postmodern ontology and postmodern ethics, namely, that of the great Austrian novelist and essayist Robert Musil, whose name has somehow remained almost entirely forgotten within this inverted Pantheon of minoritarian thinkers: if Heraclitus, Lucretius, Spinoza, and Nietzsche have come to serve as the flagships of the postmodern fleet, as the heralds of the new project of becoming, then Musil unquestionably deserves a place among them, especially if the most essential philosophical preconditions of the postmodern project are to be explored in full.

Immediately, however, we are confronted with a problem concerning the range of different types of texts in this chain. While Heraclitus, Lucretius, Spinoza, and Nietzsche are each familiar currency in nearly all philosophical circles except those having the most narrowly construed and a ahistorical notion of what it means to engage in philosophical activity, Musil would be the only novelist to appear in this freshly amended register. As we know, Lucretius was beyond doubt a remarkable poet who wrote in dactylic hexameter in order to elevate his poem to the level of the epic, as already established by Virgil and Homer; but he is, more specifically, a didactic poet who, in many passages of De rerum nature, wrote in easily identifiable arguments, indeed to such an extent that his credibility as a philosopher can hardly be questioned in any legitimate fashion. Musil's case, as novelist and essayist, raises altogether different questions: insofar as the essays presume a considerable philosophical foreground, they are not terribly problematic, but his fictional endeavors here require some further explanation.

To this end, we find some initial suggestions for thinking through such questions in Deleuze and Guattari's What Is Philosophy? Later, in the Negotiations collection, we find Deleuze once again revisiting a series of related matters, albeit more synoptically, even casually. Together these texts provide a series of useful strategies for approaching the question of what Mikhail Bakhtin was famously to treat as the polyphonic novel. ${ }^{[41]}$ As a slight variation on, or counterpart, to their theme of conceptual personae of philosophy, ${ }^{[42]}$ Deleuze and Guattari initially set forth a type of sensory becoming in their accompanying notion of the aesthetic figures of art: [43] "Conceptual becoming is heterogeneity grasped in an absolute form; sensory becoming is otherness caught in a matter of expression." But what, then, is this otherness? Here, Deleuze and Guattari are quick to respond: it is the body, or the universe of the possible ${ }^{[4]}$ - a problem that, beyond this enigmatic statement, we shall set to one side for now in order to return to it more pointedly in my concluding remarks. On this account, though, Musil seems to straddle the two realms: on the one hand, his essays would outwardly seem more to truck in conceptual personae; on the other, his fiction would outwardly seem more to truck in aesthetic figures. More perplexingly still is the manner in which the essays are often infused with aesthetic figures, and his fiction with conceptual personae. For these reasons, it would seem that Musil presents us with a significant degree of hybridization-or perhaps more a rarefied, recurrent, and highly intensified oscillation - between these two realms, which in his specific case are likely better conceived as dual modalities.

In the more catholic, less discrete, and hence probably more practicable rendering of this question as found in Negotiations, we read: "Affects [becomings that spill over beyond whoever lives through them (thereby becoming someone else)], percepts [packets of sensations and relations that live independently of whoever experiences them], and concepts are three inseparable forces, running from art into philosophy and from philosophy into art." ${ }^{45]}$ Later in the same text, Deleuze will complete this statement by adding: "Style in philosophy strains toward three different poles: concepts, or new ways of thinking; percepts, or new ways of seeing and hearing; and affects, or new ways of feeling. They're the philosophical trinity, philosophy as opera: you need all three to get things moving."[46]

If Deleuze had thus begun to conceive philosophy as opera, Peter Sloterdijk would offer yet another concept for this new art of thinking, terming it centauric literature-in a passage from The Thinker on Stage that serves as 
perfectly apt for Musil as for Nietzsche, we read:

For whatever the combination of sources and prototypes, the decisive element in it was centauric birth, that is the setting loose of an infinitely consequential artistic and philosophical double-natured eloquence within which Nietzsche's powers were bound together effectively for the first time. Only someone who has long since left his imagined audience behind can write like thissomeone who is no longer concerned with whether his actual audience will understand him. ${ }^{[47]}$

If we have learned anything from postmodern thought, it is that we should have by now lost our rigid devotion to superficial academic categories. While it is certainly true that disciplines have their own contents, that is, that philosophers generate concepts, filmmakers generate blocks of duration, scientists generate functions, etc., it is also true that these disciplines, as the later Deleuze reminds us, are quite capable of speaking to one another by virtue of their creative activity. "All of these disciplines communicate at the level of something that never emerges for its own sake, but is engaged in every creative discipline: the formation of space-times."[48] Given this presumption of the commonality of the creative act, I propose to proceed with the following discussion of Musil's significance as a quintessential postmodern thinker. Whether by virtue of his endless oscillations between conceptual personae and literary figures, his rich intimations of the three different poles of Deleuze's philosophical trinity (concepts, percepts, and affects) and the accompanying reconceptualization of philosophy as opera, or even his obvious anticipation of the recasting of otherness as the body or the universe of the possible, Musil's writings demonstrates a singularly new and revolutionary mode of postmodern expression, which is more than capable of setting new things into motion. It now remains for us to designate more fully and precisely what these new things set into motion might actually be.

III

....our time is characterized...by a tremendous spiritual romanticism that flees from the present into any and every past, looking for the holy grail of lost security. But what is generally deduced from this is the disintegration of an earlier condition that is supposed to have been more solid, the loss of dogmas and guidelines, the dissolution of bonds; in a word, a decline, and I would like to demonstrate that this despondent assumption is not necessary. The condition of the European mind today is in my view not one of decline, but rather of a not-yet-completed transition [ein noch nicht vollzogener Übergang]: not overripeness, but immaturity [keine Überreife, sondern Unreife].

- MUSIL, "The German as Symptom" (1923) [49]

Man is sick because he is badly constructed. We must decide to strip him in order to scratch out this animalcule which makes him itch to death, god, and with god his organs. For tie me down if you want to, but there is nothing more useless than an organ. When you have given him a body without organs, then you will have delivered him from all his automatisms and restored him to his true liberty.

- ARTAUD, "To Have Done with the Judgment of God" (1947/1948) ${ }^{[50]}$

When you invoke something transcendent you arrest movement, invoking interpretations instead of experimenting.

- DELEUZE, "On Philosophy" [51]

It is hardly difficult to discover the apparent affinity ${ }^{[52]}$ between Artaud's lionized text on the body without organs and Musil's unfinished masterpiece, The Man Without Qualities. If not the poem in full, the reference to Artaud's text is easily recognized in nearly every postmodern circle, by now serving as something of a touchstone among both postmodernism's most ardent adherents and virulent detractors. Musil's great novel, however, still subsists in relative obscurity, despite the stubborn fact that many critics continue to hold this work in sufficiently high regard to place its author in the esteemed company of Kafka, Proust, and Joyce, as the elite novelists and fiction writers 
of the twentieth century. At a more fundamental level, whether in the case of both the body without organs or the man without qualities, we immediately encounter the tension between the non-formed, non-organized, nonstratified, or destratified, on the one hand, and the formed, organized, or stratified, on the other, that is, the tension between something quite analogous to what Negri has conceived, on the one hand, as constitutive power (natura naturans) and, on the other, as constituted power (natura naturata)-conceptual juxtapositions to which we might add those of depth and surface, or the formative and pluralistic potency of the pure unformed and the various stages and guises of its manifold crystallizations in time. Yet if Artaud, not unlike Nietzsche, would in the end afford us a profoundly disturbing case of terminal implosion, Musil presents us with an altogether different possibility, namely, that of the hovering life-an image that he borrows handily from Nietzsche's Human, All Too Human:

Is it true, is all that remains a mode of thought whose outcome on a personal level is despair and on a theoretical level a philosophy of destruction? - I believe that the nature of the after-effect of knowledge is determined by a man's temperament: in addition to the after-effect described I could just as easily imagine a different one, quite possible in individual instances, by virtue of which a life could arise much simpler and emotionally cleaner than our present life is: so that, though the old motives of violent desire produced by inherited habit would still possess their strength, they would gradually grow weaker under the influence of purifying knowledge. In the end one would live among men and with oneself as in nature, without praising, blaming, contending, gazing contentedly, as though at a spectacle, upon many things for which one formally felt only fear. One would be free of emphasis, and no longer prodded by the idea that one is only nature or more than nature. For this to happen one would, to be sure, have to possess the requisite temperament, as has already been said: a firm, mild and at bottom cheerful soul, a temper that does not need to be on its guard against malice or sudden outbursts and in whose utterance there is nothing of snarling or sullenness - those familiar tedious qualities [jene bekannten lästigen Eigenschaften] of old dogs and men who have long been kept on the leash. A man from whom the ordinary fetters of life have fallen to such an extent that he continues to live only so as to know better must, rather, without envy or vexation be able to forego much, indeed almost everything upon which other men place value; that free, fearless hovering [jenes frei, furchtlose Schweben] over men, customs, laws and the traditional evaluation of things must suffice him as the condition he considers most desirable. He is happy to communicate his joy in this condition, and he has, perhaps, nothing else to communicate-which involves, to be sure, one more privation and renunciation. If more is nonetheless desired of him, he will, with a benevolent shake of the head, point to his brother, the free man of action, and perhaps not conceal a certain mockery in doing so: for of his 'freedom,' there is a curious tale still to be told. [53]

It was indeed this very possibility of mapping and generating the possibilities of this free, fearless hovering life that would occupy Musil's literary undertaking, in all its various modifications and iterations, from beginning to end. In a fascinating departure from the postmodernist lineage of Heraclitus, Lucretius, Spinoza, and Nietzsche, Musil would pursue a rather different series of mediators consisting principally Ralph Waldo Emerson, Nietzsche, and Rainer Maria Rilke, along with Meister Eckhart and the other mystics that he would so carefully study in Martin Buber's important edited collection of 1909, Ecstatic Confessions. During his university years at Brno, Musil's formal training was initially in mathematics and engineering, and only subsequently, upon undertaking doctoral studies at the University of Berlin (1903-1908), in philosophy and psychology - his dissertation being on Ernst Mach, the Austrian physicist and philosopher; but he had already, long beforehand, been engaged in philosophical and literary undertakings, as was manifest in the appearance of the Törless novella in 1906. By this time, of course, Musil was on increasingly intimate footing with Nietzsche's writings, much as he was with Dostoyevsky's and Emerson's as well, all the while maintaining a lasting and highly spirited, if also entirely secular, fascination with the mystics, perhaps most prominently with Eckhart, the German theologian whom, along with Emerson, is occasionally mentioned directly in The Man Without Qualities. To his credit, Musil also became an early and ardent supporter of Henri Bergson's philosophy and was among the very first fully to comprehend and celebrate the poetry of Rilke, as evidenced in his remarkable address at the poet's memorial service. ${ }^{[54]}$ In this sense, Musil's literary activity always maintained a certain distance from the dominant currents of both contemporary Viennese culture and any of his formal duties as either engineer or academic philosopher. After completing his doctorate in 1908 , in fact, he became a librarian, so as to focus more freely on his literary endeavors, and then, subsequent to 
completing his service in the Austrian Army during World War One, went to work variously as newspaper editor, press liaison officer at the Foreign Ministry, and eventually as scientific advisor to the War Ministry, all before finally abandoning any form of regular employment to become a freelance writer in 1922.

Beyond these biographical particulars, however, it is essential for present purposes to note the degree to which Musil, following Nietzsche's lead in Human, All Too Human, would put into philosophical praxis those most minimal, delicate, and supple forms of stratification for which Deleuze and Guattari would one day become so justly celebrated in A Thousand Plateaus. ${ }^{[55]}$ While it would be difficult to argue against Deleuze and Guattari's claim that Spinoza's Ethics is "the great book of the BwO,"[56] one could well place Musil's extraordinary texts on the same footing as Spinoza's, for his own singular temperament and circumstances had set him firmly on course for establishing a similarly affirmative relationship between what would later be recognized as the implicit challenge of postmodern ontology for the ethical elaboration of new forms of subjectification that might be worthy of this emerging materialist metaphysics of pure immanence and the power of the virtual, that is, of constitutive power. We find a preliminary intimation of this new imperative, of course, already at work in Nietzsche's early writings on Heraclitus and in those from his middle period on Epicurus, the heir to Democritus and Leucippus as well as the forerunner of Lucretius - and while we can only remain uncertain as to Musil's knowledge of Nietzsche's early writings, we can be quite confident that he had studied those from the middle period in great detail. In each case, we encounter descriptions that square as tightly with Spinoza's Ethics as with Musil's own broader undertakings. In Philosophy in the Tragic Age of the Greeks, we find the following summation of Heraclitean thought:

\footnotetext{
...And if the world which we see knows only coming-to-be and passing away, but no tarrying, is it possible that those qualities might constitute a different kind of world, a metaphysical one? Not a world of unity...but a world of eternal substantive multiplicities? Should our talk of coming-to-be perhaps be derived from the peculiar weakness of human insight, whereas in the true nature of things there is no coming-to-be at all, but only a synchronicity of many true realities which were not born and will not die?

...Once again he proclaims, "The one is the many."[57]
}

And we find a very similar mood in play yet again, this time in The Gay Science, when Nietzsche undertakes a type of literary portraiture in his extraordinary depiction of Epicurus:

I see his eyes gaze upon a wide, white sea, across rocks at the shore that are bathed in sunlight, while large and small animals are playing in this light, as secure and calm as the light of his eyes. Such happiness could be invented only by a man who was suffering continually. It is the eyes that have seen the sea of existence become calm, and now they can never weary of the surface and of the many hues of this tender, shuddering skin of the sea. Never before has voluptuousness been so modest. [58]

In one of the most emblematic shifts at work in the postmodern project of inverted Platonism, we no longer find ourselves faced with the discrete distinction between the eternal and the temporal, but now rather with the eternal at work within the temporal, neither as god nor idea, but as the pure unformed, the constitutive power of the virtual, as plane of immanence or plane of consistency.

If a Spinozan spirit looms large throughout The Man Without Qualities, we should nonetheless be unequivocal in stating that his name hardly figures its pages, ${ }^{[59]}$ nor, for that matter, does it appear with any significance anywhere else in Musil's writings. It therefore remains quite unclear whether or to what degree Musil was actually familiar with the particulars of Spinoza's philosophy. We know quite certainly, however, that Musil was a preeminently devoted reader of Emerson, in whom he would have undoubtedly come across the following passage: 
[Man] is the compend of time; he is also the correlative of nature. The power of man consists in the multitude of his affinities, in the fact that his life is intertwined with the whole chain of organic and inorganic being...A man is a bundle of relations, a knot of roots, whose flower and fruitage is the world. All his faculties refer to natures out of him and predict the world he is to inhabit, as the fins of a fish foreshow that water exists, or the wings in the eagle presuppose air. Insulate and you destroy him. He cannot live without a world. Put Napoleon in an island prison, let him faculties find no men to act on, no Alps to climb, no stake to play for, and he would beat the air, and appear stupid. Transport him to large countries, dense population, complex interests and antagonistic power, and you shall see that the man Napoleon, bounded by such a profile and outline, is not the virtual Napoleon. This is but Talbot's shadow;

TALBOT. No, No, I am but shadow of myself:

You are deceived, my substance is not here,

For what you see is the smallest part

And least proportion of humanity.

I tell you, Madam, were the whole frame here,

It is of such a spacious lofty pitch,

Your roof were not sufficient to contain 't.

Shakespeare, 1 Henry VI

...No man can antedate his experience, or guess what faculty or feeling a new object shall unlock, any more than he can draw to-day the face of a person whom he shall see to-morrow for the first time. ${ }^{[60]}$

Herewith one obviously enters the shimmering realm of Nietzsche's eternal return, the gateway through which the two contradictory eternities of past and future meet in the present moment [Augenblick], ${ }^{[61]}$ to be met, in this moment of decision, with either the sad passions (reactive and resentful) that accompany the spirit of gravity and the transcendent weight of constituted power or the affirmative passions (active and creative) that accompany the spirit of levity and are forever willing enter into new relations with the Dionysian labor of constitutive power.

Again, in a wonderful reworking of some of Nietzsche's most remarkable thoughts from the middle period, Musil would thus begin his exploration of the ethical ramifications of this new ontology. In Human, All Too Human, Musil had evidently read of a preliminary figure to the overman - the man with two brain-ventricles: "a higher culture must give to man a double-brain, as it were two brain-ventricles, one for the perceptions of science, the other for those of non-science: lying beside one another, not confused together, separable, capable of being shut off; this is a demand of health." [62] For Musil, a man of astonishing capacities in the realms of both the sciences and nonsciences, it was a beacon call to rethink the relationship between the relatively determinate world of knowledge (savoir) and power (pouvoir) and the relatively indeterminate world of subjectification-a task of immense significance given the increasingly confused nature of constituted power in the early-twentieth century (not to mention what we might here underscore, with some dark irony, as the wildly reactionary and eventually fascist double lurking within constitutive power itself). In this sense, Musil would open the door to a highly alert and adaptive reconceptualization of what Deleuze would many years later designate as "a specific dimension without which we can't go beyond knowledge (savoir) or power (pouvoir)."[63] As we read in Musil's "Sketch of What the Writer Knows" (1918): "The task [of the writer] is to discover ever new solutions, connections, constellations, variables, to set up prototypes of an order of events, appealing models of how one can be human, to invent the inner person."[64]

Borrowing from his scientific training, Musil would cast his conceptualization of the ratioid and the nonratioid in the relative terms of solids and fluids. Drawing yet again from his "Sketch of What the Writer Knows," we encounter the realm of that which is relatively solid, even if only illusorily so, in the ratioid: 
The ratioid area is characterized by a certain monotony of facts, by the predominance of repetition, by a relative independence of facts from one another, so that they can usually be joined to previously formed groups of laws, rules, and concepts in whatever sequence they may have been discovered; but above all the chief characteristic of this area is that in it facts can be unambiguously described and communicated...One can say that the ratioid area is dominated by the concept of the fixed and solid, and by the deviation that it excludes from consideration; a concept of the fixed as a fictio cum fundamento in re [fiction with a basis in fact]. Here, too, at the lowest level, the ground is shaky; the most basic principles of mathematics are logically unsecured; the laws of physics have only an approximate validity, and the constellations move in a system of coordinates that nowhere has a locus. But still one hopes, not without reason, to bring order to all this, and Archimedes' statement of over two thousand years ago, "Give me a fixed place to stand and I will move the world!" is even today the expression for our hopeful behavior. ${ }^{[65]}$

And, in turn, the realm of that which is relatively fluid in the nonratioid:

If the ratioid is the area of the domination of the "rule with exceptions," the nonratioid area is that of the dominance of the exceptions over the rule... In this region facts do not submit, laws are sieves, events do not repeat themselves but are infinitely variable and individual. There is no better way to characterize this region than to point out that it is the area of the individual's reactivity to the world and other individuals, the realm of values and valuations, of ethical and aesthetic relationships, the realm of the idea. ${ }^{[66]}$

In part coda and in part synthesis, Musil concludes these remarks with the following statement, which serves as testimony to the preliminary outlines of a new form of subjectification, namely, the hovering life: "The significant person is the one who commands the greatest factual knowledge and the greatest degree of rationality in connecting the facts: in the one area as in the other. But one person finds the facts outside himself and another within himself; one meets with coherent sequences of experience and another doesn't."[67]

Setting to one side the questions of knowledge (savoir) and power (pouvoir), the task before us in the remaining pages of this essay consists in identifying the means by which this new subjectivity is produced, for, again, as Deleuze says of the distinct departure taken by Foucault in his later writings:

The problem changes, and something new is created. The simple fact that subjectivity is produced, that it's a "way," should be enough to convince one the word should be treated very carefully. Foucault says "an art of oneself that's the exact opposite of oneself..." If there's a subject, it's a subject without any identity. Subjectification as a process is personal or collective individuation, individuation by one or a group. ${ }^{[68]}$

The groundless ground thus gives way to the subjectless subject; the body without organs to the man without qualities: the plane of immanence or plane of consistency, a non-formed, non-organized, non-stratified, or destratified body or term. It would obviously be quite ridiculous to endeavor to reduce Musil, Deleuze, Foucault, or Negri to one another, but there is clearly more than a vague affinity between these various projects, and indeed an affinity that deserves to be mined much more fully than is possible in these pages. For present purposes, however, two problems still stand before us: first of all, it remains to be seen precisely how Musil would help to re-inaugurate an age of what Peter Sloterdijk, following Foucault, has described as one of anthropotechics, ${ }^{[69]}$ that is, the technologies of the self, or these most minimal, delicate, and supple of stratifications given expression in the conceptual persona of Musil's man without qualities; and, secondly, we must also demonstrate more precisely how these anthropotechnics set forth by Musil pertain more directly to the advent of postmodern thought as it emerged in the post-1968 period. 
My hypotheses [sic]: the subject as multiplicity.

- NIETZSCHE, The Will to Power [70]

The thought is not something that observes an inner event [ein innerlich Geschehene], rather it is this inner event itself [dieses innerlich Geschene selbst].

We do not reflect on something, rather something thinks itself up and out of us. The thought does not consist in our seeing something clearly that has developed within ourselves, rather it is an inner development that stretches out into this bright area.

- MUSIL, Diaries [71]

Musil had read in Emerson's essay on "The Poet" that the "man is only half himself, the other half is his expression." "72] But he also knew, in his carefully conceived reception of Nietzsche and his unknowing intimations of the future Deleuze, that this inner event of expression was often more than capable of overwhelming the constituted/stratified subject and must therefore be appropriated with the greatest selectivity. ${ }^{\text {[73] Nietzsche's }}$ appropriation of Darwin ${ }^{[74]}$ obviously remains a stubborn problem in its own right to this day, but there is no doubt that the problem of selection was every bit as significant for the series reaching from Nietzsche to Deleuze, just as it was in another series reaching from Nietzsche to Max Weber and indeed Musil himself. The imperative of selection-in this Heraclitean "world of eternal substantive multiplicities,"[75] in which "the true nature of things" [76] is "a synchronicity of many true realities which were not born and will not die"[77]_is occasioned by multiplicity itself, for the "one is at the same time the many." ${ }^{[78]}$ Nietzsche had reconstructed this Heraclitean formulation in numerous places throughout his writings, but we find one of the most concise and precise statements in one of his jottings from the later notebooks: "Man as a multiplicity of 'wills to power': each one with a multiplicity of means of expression and forms." [79] In order, as Musil so clearly understood, "to discover ever new solutions, connections, constellations, variables, to set up prototypes of an order of events, appealing models of how one can be human, to invent the inner person," [80] the only way one could avoid the terminal implosion of schizophrenia or psychosisof allowing a momentary stage in the psychic development of young Törless to become the terminal implosion of the sado-fascistic Moosbrugger - would be to achieve the minimal stratification necessary for proceeding with a virtually acrobatic degree of both stability and flexibility in the critical (selective) appropriation of forces.

On this account in particular, Sloterdijk has brilliantly reformulated the dual problem of selection and asceticism in such a way as to prove an invaluable corrective to the frequent and terrifically misleading overstatements found throughout Nietzsche's own writings:

\footnotetext{
....it is relevant to observe that the word áskesis...simply means 'exercise' or 'training' in ancient Greek. In the wake of his new division of ascetic opinion, Nietzsche not only stumbles upon the fundamental meaning of the practising life for the development of styles of existence or 'cultures.' He puts his finger on what he sees as the decisive separation for all moralities, namely into asceticisms of the healthy and the sick, though he does not show any reservations about presenting the antithesis with an almost caricatural harshness. The healthy-a word that has long been subjected to countless deconstructions-are those who, because they are healthy, want to grow through good asceticisms; and the sick are those who, because they are sick, plot revenge with bad asceticism. ${ }^{[81]}$
}

And indeed, Musil has a name for this new asceticism; he calls it essayism and conceives it, in essence, as a means of linking the insights of the hovering life with the constitutive power of subjectification: 
There was something in Ulrich's nature that in a haphazard, paralyzing, disarming way resisted all logical systematizing, the single-minded will, the specifically directed drives of ambition; it was also connected with his chosen term, "essayism," even though it contained the very elements he had gradually and with unconscious care eliminated from that concept. The accepted translation of "essay" as "attempt" contains only vaguely the essential allusion to the literary model, for an essay is not a provisional or incidental expression of a conviction capable of being elevated to a truth under more favorable circumstances or of being exposed as an error (the only ones of that kind are those articles or treatises, chips from the scholar's workbench, with which the learned entertain their special public); an essay is rather the unique and unalterable form assumed by a man's inner life in a decisive thought. Nothing is more foreign to it than the irresponsible and half-baked quality of thought known as subjectivism. Terms like true and false, wise and unwise, are equally inapplicable, and yet the essay is subject to laws that are no less strict for appearing to be delicate and ineffable. There have been more than a few such essayists, masters of the inner hovering life [Meister des innerlich schwebenden Lebens], but there would be no point in naming them. Their domain lies between religion and knowledge, between example and doctrine, between amor intellectualis and poetry; they are saints with and without religion, and sometimes they are also simply men on an adventure who have gone astray. ${ }^{[82]}$

This may strike us, of course, as merely a lingering Emersonian nicety, but essayism, for Musil rather, is precisely the means through which the minimal and rarefied stratification of the nonratioid-like a Deleuzo-Guattarian surfer poised in the full motion of an unfolding wave ${ }^{[83]}$ - makes sense of the non-formed, non-organized, non-stratified, or destratified body or term. Essayism thus serves as nothing less than the means through which sense, like everything else in nature, is generated, produced, brought formally into play; and in turn we find in Foucault's later writings a famous remark that resonates quite perfectly with this essayistic moment of individuation.

There are times in life when the question of knowing if one can think differently than one thinks, and perceive differently than one sees, is absolutely necessary if one is to go on reflecting at all...[W]hat is philosophy today - philosophical activity, I mean -if it is not the critical work that thought brings to bear on itself? In what does it consist, if not in the endeavor to know how and to what extent it might be possible to think differently, instead of legitimating what is already known...[Philosophical discourse] is entitled to explore what might be changed, in its own thought, through the practice of a knowledge that is foreign to it. The "essay" - which should be understood as the assay or test by which, in the game of truth, one undergoes changes, and not as the simplistic appropriation of others for the purpose of communication-is the living substance of philosophy, at least if we assume that philosophy is still what it was in times past, i.e., "ascesis," askesis, an exercise of oneself in the activity of thought. ${ }^{[84]}$

For the postmodernists, essayism would in this sense effectively serve as one of the chief realms of philosophical experimentation in the skilled modulation (techne) of an as yet disparate series of intensities now mediated by the doubling of the play of forces at work in the new praxis of thought, for, as part and parcel of culture, thought is nothing if not itself generated from a process of training and selection, ${ }^{[85]}$ that is, from nature itself-as we read in Deleuze:

Nietzsche...explored a world of impersonal and pre-individual singularities, a world he then called Dionysian or of the will to power, a free and unbounded energy. These are nomadic singularities [that] are no longer imprisoned within the fixed individuality of the infinite Being (the notorious immutability of God), nor inside the sedentary boundaries of the finite subject (the notorious limits of knowledge). This is something neither individual nor personal, but rather singular. Being not an undifferentiated abyss, it leaps from one singularity to another, casting always the dice belonging to the same cast, always fragmented and formed again in each throw. It is a Dionysian sense-producing machine, in which nonsense and sense are no longer found in simple opposition, but are rather co-present to one another within a new discourse. The new discourse is no longer that of the form, but neither is it that of the formless: it is rather that of the pure unformed...As for the subject of this new discourse (except that there is no longer any subject), it is not man or God, and even less man in the place of God. The subject is this free, anonymous, and nomadic singularity [that] traverses men as well as plants and animals independently of the matter of their individuation and the forms of their personality. "Overman" means nothing other than this-the superior type of everything that is. This is a strange discourse, which ought to have renewed philosophy, and which finally deals with sense not as a predicate or a property but as an event. ${ }^{[86]}$ 
The decisiveness ${ }^{[87]}$ of this revelation, ${ }^{[88]}$ of this fulgurating "point of transmutation or transvaluation,"[89] constitutes the event of events for postmodern thought, its very core and essence, and we who accept its challenge to transform this new ontology into an ethic advance no step further in the absence of acknowledging it as such-for, in the new time of Aion,[90] "[p]hilosophy's sole aim is to become worthy of the event."[91]

\section{V}

...to depict man's understanding as wandering below the unthinkable.

- HÖLDERLIN, "Remarks on Antigone" [92]

But on the day we can say with all our hearts, "Onwards! our old morality too is part of the comedy!" we shall have discovered a new complication and possibility for the Dionysian drama of "The Destiny of the Soul" - and one can wager that the old eternal comic poet of our existence will be quick to make use of it!

- NIETZSCHE, On the Genealogy of Morals [93]

I have endeavored in the preceding pages to open a pathway towards situating Robert Musil within the great line of minoritarian thinkers now typically construed as the forerunners of the postmodern philosophical project, particularly in terms of their shared affinity for a highly distinctive range of problems pertaining to the realms of ontology and ethics. To this end, as with all the most extraordinary literary creations and constructions, it would seem almost inevitable that there would be an element of the tragicomic in these writings. As with the later Oedipus, who was once the most knowledgeable, skilled, and powerful of men, all while never achieving true philosophical insight until he had committed the unspeakable and become godless (atheos), ${ }^{[94]}$ our postmodern condition and its new categorical imperative of self-constitution would seem, metaphorically at least, to rhyme with this state of affairs, leaving us similarly destitute in our now simultaneously enlightened and yet strangely eclipsed wanderings. Insofar as the minimal shelter and security afforded by postmodern ontology may well serve as the essential precondition for the aspect of Deleuze's grand vivant ${ }^{[95]}$ in all the potentiality of its ethical character, it would seem we may have nonetheless become forever-wandering post-theistic, post-Platonic, and indeed even post-Freudian Oedipuses, devoid of any last lingering recourse to representation. Hence the homelessness ${ }^{[96]}$ once described by Nietzsche and the corresponding necessity of giving style to one's character, ${ }^{[97]}$ or, as Deleuze says, of "bending force back on itself, by setting force in a relation to itself" [98] in a continual process of selection, combination, and synthesis achieved through the power of the virtual: the overman as postmodern destiny. ${ }^{\text {[99] }}$

In Musil's formulation, to return once again from "Sketch of What the Writer Knows," we discover a profound statement to this end: "The significant person is the one who commands the greatest factual knowledge and the greatest degree of rationality in connecting the facts...But one person finds the facts outside himself [the ratioid] and another within himself [the nonratioid]."[100] What precisely was it, then, that Musil had discovered in his formulation of this problem? I can only respond to this question by way of reference to Deleuze, ${ }^{[101]}$ Foucault, ${ }^{[102]}$ and ultimately Maurice Blanchot, the brilliant literary critic who had written so astutely on Musil's great unfinished novel in The Book to Come and who was also likely responsible for introducing his colleagues to whatever they may have known of the vast philosophical terrain opened by the great Austrian thinker: ${ }^{[103]}$ Musil set out to explore what Deleuze would later characterized as "our double, with all the double's otherness,"[104] in the thought from outside; ${ }^{[105]}$ the beyond, the untimely, the overman; indeed all that whirls on the other side of representation, all that shimmers and roils on the outside of the inner soul of consciousness and the inner essence of the concept; what Musil in one place calls, as if delicately poised on the plane of immanence or the plane of consistency, the "wheeling and revolving of things"[106] _ and that is precisely why he belongs in this venerable and foreboding train of thought. In his invention and deployment of the ever-shifting relationship between the nonratioid and the hovering life (constitutive power), on the one hand, and ratioid or more slowly shifting factual life (constituted 
power), he offers us a novel glimpse into the postmodern command of empirical and historical knowledge and the corresponding productivity at work in connecting the facts; a rationality that somehow always goes beyond this factual knowledge in what Deleuze would eventually cast as transcendental empiricism.

We thus do a great injustice to Nietzsche and his heirs whenever we stoop to bombastic renderings of the overman, a figure who instead moves on light and dewy feet. Nietzsche himself, in fact, characterized Goethe as the modern exemplar of this figure for his having successfully integrated the scientific and non-scientific in a singular character that spanned the ages. ${ }^{[107]}$ In turn, I would argue, Musil may readily be seen as another such overman, an anti-foundational analog to Goethe, stemming from the most powerful tendencies within what would in time be recognized as the postmodern gambit, for the author of The Man Without Qualities likewise spans the ages in his untimeliness. "The only remaining question,"[108] Musil reminds us, "is whether the writer should be a child of his time or a begetter of the ages."[109] And, as if to answer his own question, in an entry in the Diaries, made sometime during the course of the 1930s, he writes: "Th[omas] M[ann] and similar authors write for the people who are there; I write for people who aren't there." ${ }^{[110]}$ In his "Address at the Memorial Service for Rilke in Berlin," he concludes with words that might have just as easily been said of himself: "And someday he [Rilke] will be seen to have been not only a great poet, but a greater leader on the path [Weg] that leads from [von] the religious world-view [religiösen Weltgefüh/] of the Middle Ages through [über] the humanistic ideal of culture [humanistische Kulturideal] to a worldview [Weltbild] yet to come."[111]

But what exactly is meant by this path, this way, that leads from the religious world-feeling of the Middle Ages through the humanistic ideal to a world-image yet to come? Where is the austere repose of Musil's Rilkean sensibilities, with all their openness to his most sublimely molecular becomings, in this rattling and jarring hum of the postreligious and posthuman condition? Presuming it is reasonable to infer an approximate relationship between the posthuman and the postmodern, are we not perpetually vexed at these supposedly novel fields of thought that continually rediscover their roots not only in eras substantially prior to the supposed revelations of the period surrounding 1968 but occasionally even in the remoter ages of Antiquity? Have we not by now grown weary of these stubborn aporias of increasingly established fields of thought that continually rediscover their trajectories in some path, or way, rather than in the locus of a stable identity? And do we not find these difficulties all the more confounding still as we ourselves struggle with distinguishing between humanism and radical humanism, ${ }^{[112]}$ or posthumanism and radical posthumanism, etc., indeed much as we once endeavored to distinguish between modernism and postmodernism, or structuralism and poststructuralism? "Words, words-nouns,"[113] Sloterdijk exclaims: "They need only to open their wings, and millennia fall out of their flight."[114]

In their "Humanity Without Itself: Robert Musil, Giorgio Agamben and Posthumanism," Ivan Callus and Stefan Herbrechter offer some important suggestions with regard to how we might potentially work our way through these various aporias. Explicitly declaring their program of exploring "'a posthumanism without technology,' that is, a posthumanism not driven solely by technological considerations," [115] their purpose in this piece ostensibly consists in establishing a bridge between the existing field of that which remains "within the literary culture and within the theoretical humanities that might be worth revisiting by mainstream, technology-minded posthumanism."[116] While in no way downplaying the increasingly ubiquitous and hegemonic pretenses of technoculture, their essay raises the question of what it might perhaps mean to be human in an age in which humanism is increasingly exhausted and no longer capable of responding to the complexity of a pervasive technoculture ${ }^{[117]}$ _ something of which both Rilke ${ }^{[118]}$ and Musil ${ }^{[19]}$ had experienced palpable intimations. Yet, as Callus and Herbrechter conclude, even in this avowedly delimited venture of discerning some lingering aspect of the human in the likely absence of humanism, we inevitably encounter yet another fundamental aporia: "we are up against the paradox that art, that human(ist) quality, may need to go unindulged for (post)human poetry to take root again."[120]

In his treatment of the "superfold"[121] of the overman, Deleuze hardly fares any better in finding a viable means of escaping a very similar aporia - though, to be fair, his suggestions concerning the overman of the superfold as the man who is in charge of the animals, inorganic matter, and language is undoubtedly rich in implications. While, in 
his important Appendix to the Foucault text, he clearly identifies the new configurations of knowledge (one must wonder if its counterpart in power is perhaps roughly outlined in another piece appearing several years later ${ }^{[122]}$ ), especially insofar as postmodern man is unquestionably entering into relations with a new set of forces, Deleuze somehow overlooks a number of the potentially far more engaging discussions of subjectification found elsewhere in his writings and interviews. Posing the problem yet again within the historical problématique (here, obviously, in conjunction with Foucault's schematization rather than Musil's), Deleuze seems, curiously, to sidestep many of the more provocative suggestions regarding the process of subjectification detailed in Foucault's later writings (and, in fact, even in his own account of them in this same very text $\left.{ }^{[123]}\right)$ : "[W]hat new form will emerge that is neither God nor Man? This is the correct place for the problem which Nietzsche called the [overman]."[124] In Deleuze's treatment, as is well known, the God-form of the "Classical"[125] historical formation and the Man-form of the "Nineteenth-Century" ${ }^{[126]}$ historical formation are contingent upon the forces with which the forces within man enter into relations, such as, respectively, the "forces that raise to infinity (the unfold) and the forces of finitude (the fold)."[127] The superfold of the postmodern age would in turn entail man, now expressed as overman, entering into relations with the new forces of genetic components (superseding the organism), silicon (superseding carbon), and agrammaticalities (superseding the signifier); ${ }^{[128]}$ but, in this account at any rate, we read very little from Deleuze that might serve as a means of engaging any of the emergent problems facing the processes of subjectification, that is, the problematic question of one's relation to oneself in the postmodern age.

For recommendations to this end, we must instead turn to two very insightful passages from Paul Veyne's wonderful text on Foucault, in which we find the following remarkable quotation: "We must do without mankind and human nature if we wish to analyze the system of society and human beings." [129] Later, in these same pages, Veyne will add the following: "So man has never ceased 'to constitute himself in the infinite and multiple series of different subjectivities that will never come to an end' and we never come 'face to face with something that is man..." "130] Veyne's remarks, of course, remain at the most general level, but it is not difficult to sense their deeper ramifications, for the only truly fundamental question that remains is whether this process is active or reactive. ${ }^{[131]}$

We know of Giaccomo Leopardi's extraordinary encounter with "superhuman silences"[132] and also of Dino Campana's apparent rejoinder to this "infinite silence"[133] in the prospect of "man being reborn reconciled with nature, ineffably sweet and frightening." [134] At present, we quite evidently have many different and occasionally highly disparate definitions of what it might mean, as Campana says, to be "beyond the human [trasumanati],"[135] but we may nevertheless be certain, as we have already read from Lucretius, that the constitutive power at work in forming whatever contours man might assume is not merely that of the overman but also that of the overman's relation to the prehuman, that is, to nature itself. Here, to be sure, one can hardly help but to cite Spinoza's bold words in which the term God is shorn from its traditional theistic moorings as a transcendent-moral being and simultaneously reconceived as natura naturans, a being whose "power is his very essence":[136]

From this fact therefore, that is, that the power whereby natural things exist and operate is the very power of God itself, we easily understand what natural right is. For as God has a right to everything, and God's right is nothing else, but his very power, as far as the latter is considered to be absolutely free; it follows from this, that every natural thing has by nature as much right, as it has power to exist and operate; since the natural power of every natural thing, whereby it exists and operates, is nothing else but the power of God, which is absolutely free. ${ }^{[137]}$

The power of self-constitution, that is, of subjectification, is therefore none other than the bending back of force upon itself, the bending back of the power that lies outside, beyond all representation; it is, in other words, the folding of the as yet unthought ${ }^{[138]}$ or the virtual - the generation of a given human form in conjunction with the prehuman power of nature itself (natura naturans, puissance, or the will to power) albeit in a manner quite distinct from knowledge (savoir) or power (natura naturata or pouvoir). 'It is not the emanation of an 'I,' but of something that places in immanence an always other or Non-self,"[139] writes Deleuze. 
Thus we may once again, a fortiori, identify the subject of this new discourse as a "Dionysian sense-producing machine"[140]: a "free, anonymous, and nomadic singularity [that] traverses men as well as plants and animals independently of the matter of their individuation and the forms of their personality."[141] While it is certainly true that Nietzsche was among the most important figures to explore this new "world of impersonal and pre-individual singularities," it is equally true that Musil would soon become the immediate heir to this great project, deploying the fluctuating relations between the nonratioid and ratioid as ever-changing and perpetually self-reconstituting fields of the transcendental and the empirical, that is, of the genetic oscillations within the field of transcendental empiricism. ${ }^{[142]}$ In one of the most remarkable, if also easily overlooked, passages of Spinozan parallelism in The Man without Qualities, Ulrich says chidingly to Clarisse, as if she might become something other than the mere product of an existing dispositif: "Because an idea is what you are: an idea in a particular state. You are touched by a breath of something, and it's like a note suddenly emerging from the humming of strings; in front of you there is something like a mirage; out of the confusion of your soul an endless parade is taking shape, with all the world's beauty looking on from the roadside."[143]

Following Deleuze and Guattari's reconceptualization of ethology in A Thousand Plateaus, ${ }^{[144]}$ Hasana Sharp has suggested something similar might be pursued with regard to a posthumanist understanding of man. ${ }^{[45]}$ Yet, as had already been stated many years earlier in Anti-Oedipus, it is upon this very ethological plane of immanence at work in the formation of "space-times," of "the universal power to affect and be affected,"[146] not least by the "ontological praxis of truth"[147]_that Homo natura in the indeterminate end turned out to be Homo historia: ${ }^{[148]}$ a subjectless subject, "an artistically creating subject," [149] in its most astonishing moments embracing the alterity of the pure unformed in the fulgurating union that comprises the event: ${ }^{[150]}$ its singular means of self-dissolution and self-constitution ${ }^{[151]}$-its own self-constitutive event returning with each revelation of being, ${ }^{[152]}$ its entire train of past transvaluations endlessly reemerging in anticipation of a prodigious future yet to come. Musil, in this sense, gave us the great architecture of the best and most robust forces that postmodernism still has to offer us; he gave us some of our first words for the manner in which the most powerful forces of subjectification would henceforth arrive from outside of ourselves, "like drops of fire falling into the world," [153] without descending from some a priori determination: the posthuman, now thought from the prehuman outside that lies within.

In keeping with our initial citation of Heraclitus, the primordial thinker of the thunderbolt that steers all things, ${ }^{[154]}$ it may one day be said that with Musil we enter not only the Aionic time of postmodernity, but, perhaps more appropriately still, a secular age of the fulguratores.

\section{Bibliography}

Agamben, Giorgio. The Man Without Content. Trans. Georgia Albert. Stanford: Stanford UP, 1999.

Allison, David B., ed. The New Nietzsche. Cambridge: MIT P, 1985.

Ansell Pearson, Keith. "A Superior Existentialism." Pli: The Warwick Journal of Philosophy, 9 (2000): 248-256.

Artaud, Antonin. Four Texts. Trans. Clayton Eshleman and Norman Glass. Los Angeles: Panjandrum, 1982.

Bakhtin, Mikhail. Problems of Dostoyevsky's Poetics. Ed. and Trans. Caryl Emerson. Minneapolis: U of Minnesota P, 1984.

Benn, Gottfried. Gesammelte Werke I: Essays, Reden, Vorträge. Ed. Dieter Wellershof Wiesbaden: Klett-Cotta, 1977.

Blanchot, Maurice. The Book to Come. Stanford: Stanford UP, 2003.

Campana, Dino. Canti Orfici/Orphis Songs. Trans. Luigi Bonaffini. Boca Raton: Bordighere P, 2003. 
Deleuze, Gilles, and Félix Guattari. Anti-Oedipus: Capitalism and Schizophrenia. Trans. Robert Hurley, Mark Seem, and Helen R. Lane. Minneapolis: U of Minnesota P, 1983.

- - . A Thousand Plateaus: Capitalism and Schizophrenia. Trans. Brian Massumi. Minneapolis: U of Minnesota P, 1987.

- - What Is Philosophy? Trans. Hugh Tomlinson and Graham Burchell. New York: Columbia UP, 1994.

Deleuze, Gilles. Nietzsche and Philosophy. Trans. Hugh Tomlinson. New York: Columbia UP, 1983

- - Foucault. Ed. and Trans. Seán Hand. Minneapolis: U of Minnesota P, 1988a.

- - Spinoza: Practical Philosophy. Trans. Robert Hurley. San Francisco: City Lights, $1988 b$.

- - The Logic of Sense. Ed. Constantin V. Boundas, Trans. Mark Lester and Charles Stivale. New York: Columbia, 1990.

- - Expression and Philosophy: Spinoza. Trans. Martin Joughin. New York: Zone, 1992.

- - Difference and Repetition. Trans. Paul Patton. New York: Columbia UP, 1994.

- - Negotiations, 1972-1990. Trans. Martin Joughin. New York: Columbia UP, 1995.

- - Essays Critical and Clinical. Trans. Daniel W. Smith and Michael A. Greco. Minneapolis: Minnesota UP, 1997.

- - . Desert Islands and Other Texts, 1953-1974. Ed. David Lapoujade, Trans. Michael Taormina. Los Angeles:

Semiotext(e), 2004.

- - Nietzsche and Philosophy. Trans. Hugh Tomlinson. New York: Columbia UP, 2006.

- - Two Regimes of Madness: Texts and Interviews, 1975-1995. Ed. David Lapoujade, Trans. Ames Hodges ana Mike Taormina. South Pasadena: Semiotext(e), 2017.

Dosse, François. Gilles Deleuze and Félix Guattari: Intersecting Lives. Trans. Deborah Glassman. New York: Columbia UP, 2010.

Eckhart, Johannes (Meister Eckhart). Selected Writings. Ed. and Trans. Oliver Davies. London: Penguin, 1994.

Emerson, Ralph Waldo. Emerson's Essays: First and Second Series Complete in One Volume. New York: Harper \& Row, 1926.

Foucault, Michel. Language, Counter-Memory, Practice: Selected Essays and Interviews by Michel Foucault. Ed. Donald F. Bouchard. Ithaca: Cornell UP, 1977

- - The History of Sexuality, Volume II: The Use of Pleasure. Trans. Robert Hurley. New York: Pantheon, 1985.

Foucault, Michel, and Maurice Blanchot. Maurice Blanchot: The Thought from the Outside/Michel Foucault as I Imagine Him. New York: Zone, 1990.

Guattari, Félix. Chaosmosis: An Ethico-Aesthetic Paradigm. Trans. Paul Bains and Julian Pefanis. Bloomington: Indiana UP, 1995.

Hölderlin, Friedrich. Essays and Letters on Theory. Ed. and Trans. Michael Pfau. Albany: State U of New York, 1988. - - Selected Poems and Fragments. Ed. Jeremy Adler, Trans. Michael Hamburger. Harmondworth, Middlesex, England: Penguin, 1998.

Jaspers, Karl. Nietzsche: An Introduction to the Understanding of His Philosophical Activity. Trans. Charles F. Wallraff and Frederick J. Schmitz. Baltimore: Johns Hopkins UP, 1997.

Klossowski, Pierre. Nietzsche and the Vicious Circle. Trans. Daniel W. Smith. London: Conyinuum, 2005. 
Leopardi, Giaccomo. Canti. Ed. and Trans. Jonathan Galassi. New York: Farrar Straus Giroux, 2010.

Mousley, Andy, ed. Towards a New Literary Humanism. London: Palgrave Macmillan, 2011.

Murphy, Timothy S., and Abdul-Karim Mustapha, eds. The Philosophy of Antonio Negri: Resistance in Practice. London: Pluto, 2005.

Musil, Robert. Five Women. Trans. Eithne Wilkins and Ernst Kaiser. Boston: David R. Godine, 1986.

- - Precision and Soul: Essays and Addresses. Ed. and Trans. Burton Pike and David S. Luft. Chicago: U of Chicago P, 1990.

- - The Man Without Qualities, Volume I. Trans. Sophie Wilkins. New York: Vintage, 1995a.

- - The Man Without Qualities, Volume II. Trans. Sophie Wilkins. New York: Vintage, 1995b.

- - Diaries, 1899-1941. Ed. Mark Mirsky, Trans. Philip Payne. New York: Basic, 1998.

- - The Confusions of Young Törless. Trans. Shaun Whiteside. New York: Penguin, 2001.

Negri, Antonio. The Savage Anomaly: The Power of Spinoza's Metaphysics and Politics. Minneapolis: $U$ of Minnesota P, 1991.

- - "On Gilles Deleuze and Félix Guattari, A Thousand Plateaus." Trans. Charles T. Wolfe. Graduate Faculty Philosophy Journal, 18:1 (1995): 93-109.

- - Subversive Spinoza: (Un)Contemporary Variations. Ed. Timothy S. Murphy, Trans. Timothy S. Murphy, Michael Hardt, Ted Stolze, and Charles T. Wolfe. Manchester: Manchester UP, 2004.

- - Time for Revolution. Trans. Matteo Mandarini. London: Continuum, 2005.

Nietzsche, Friedrich. Philosophy in the Tragic Age of the Greeks. Trans. Marianne Cowan. Washington, DC: Gateway (Regnery), 1962.

- - The Will to Power. Ed. Walter Kaufmann, Trans. Walter Kaufmann and R.J. Hollingdale. New York: Vintage, 1967.

- - Nietzsche: A Self-Portrait from His Letters. Ed. and Trans. Peter Fuss sand Henry Shapiro. Cambridge: Harvard UP, 1971.

- - The Gay Science, with a Prelude in Rhymes and an Appendix of Songs. Trans. Walter Kaufmann. New York: Vintage, 1974.

- - The Portable Nietzsche. Ed. and Trans. Walter Kaufmann. Harmondsworth, Middlesex, England: Penguin, 1982.

- -. Werke III. Frankfurt/M: Ullstein Materialien, 1984.

- - Human, All Too Human: A Book for Free Spirits. Trans. R.J. Hollingdale. Cambridge: Cambridge UP, 1996.

- - Basic Writings of Nietzsche. Trans. Walter Kaufmann. New York: Modern Library, 2000.

- - Writings from the Late Notebooks. Ed. Rüdiger Bittner, Trans. Kate Sturge. Cambridge: Cambridge UP, 2003.

Parr, Adrian, ed. The Deleuze Dictionary. New York: Columbia UP, 2005.

Rilke, Rainer Maria. The Notebooks of Malte Laurids Brigge. Trans. M.D. Herter Norton. New York: W.W. Norton, 1964.

Roy, M.N. Radical Humanist: Selected Writings. Ed. Innaiah Narsetti. Amherst: Prometheus, 2004. 
Shakespeare, William. King Lear. New York: Signet, 1998.

Sharp, Hasana. Spinoza and the Politics of Renaturalization. Chicago: U of Chicago P, 2011.

Sloterdijk, Peter. Critique of Cynical Reason. Ed. Andreas Huyssen, Trans. Michael Eldred. Minneapolis: U of Minnesota P, 1987.

- - The Thinker on Stage: Nietzsche's Materialism. Trans. Jamie Owen Daniel. Minneapolis: U of Minnesota P, 1989.

- - You Must Change Your Life. Trans. Wieland Hoban. Cambridge: Polity, 2013

Sophocles. Sophocles, I (Third Edition). Ed. David Grene and Richard Lattimore. Trans. Robert Fitzgerald, David Grene, and Elizabeth Wyckoff. Chicago: U of Chicago, 2013.

Spinoza, Baruch. A Theologico-Political Treatise/A Political Treatise. Trans. R.H.M. Elwes. New York: Dover, 1951

- - The Ethics and Selected Letters. Ed. Seymour Feldman, Trans. Samuel Shirley. Indianapolis: Hackett, 1982.

Stivale, Charles J., ed. Gilles Deleuze: Key Concepts. Chesham, Bucks: Acumen, 2005.

Strauss, Leo. Thoughts on Machiavelli. Chicago: U of Chicago P, 1978.

Smith, Daniel W. Essays on Deleuze. Edinburgh: U of Edinburgh P, 2012.

Veyne, Paul. Foucault: His Thought, His Character. Cambridge: Polity, 2010.

\section{Notes}

1. Heraclitus, in Kirk, Raven, and Schofield, eds, 2003 \{Chapter VI, §232 (Fr 45), p. 203\}

2. Deleuze, 1994 \{Chapter I, p. 67\}

3. Strauss, 1978 \{Chapter III, p. 123\}

4. Negri, $1995\{\S 1$, p. 93$\}$

5. Deleuze, in Allison, ed, 1985 \{"Nomad Thought," p. 148\}

6. Deleuze, in Allison, ed, 1985 \{“Nomad Thought," p. 144\}

7. see Deleuze, 1994 \{Chapter I, p. 35, and Conclusion, pp. 301-304\}-see also Deleuze, 1990 \{Appendix I, pp. 264-265\}

8. see, for example, Deleuze, 1995 \{Part Four, "Philosophy": “Mediators," pp. 125-127\}

9. For complex reasons, which would likely require an altogether different essay or series of essays, I must for the time being set to one side the highly problematic names of Hölderlin, Leopardi, Freud, and Heidegger in particular.

10. see, for example, Negri, 1991 \{Preface, p. 17\}

11. see, for example, Jaspers, 1997 \{Book Two: "The Basic Thoughts of Nietzsche", Chapter Five: "World Exegesis": "The World as Pure Immanence," pp. 319-330\}

12. see, for example, Negri, 1995 (§।, pp. 95-96)

13. see, for example, Veyne, 2010 \{Chapter 3, p. 42, and Chapter 8, p. 104\}

14. Nietzsche, 1984 \{"Wissenschaft und Weisheit im Kampfe," pp. 1052-1053\}, translation in Deleuze, 2006 \{Chapter 3, §13, p. 101\}-see also Deleuze, 1995 \{Part Four, "Philosophy”: "On Philosophy,” p. 143\}

15. see, for example, Deleuze, 1994 \{Chapter I, pp. 56-59, and Chapter II, p. 86-89\}

16. see, for example, Deleuze, 1994 \{Chapter I, pp. 66-69, and Chapter III, pp. 153-155\}

17. see, for example, Deleuze, 1995 \{Part Three, "Michel Foucault": “A Portrait of Foucault," pp. 113-114\}

18. see, for example, Campana, in Negri, 2005 \{Time for Revolution: Multitudo, Prolegomena, p. 209\}; Campana, 2003 \{“Pampa," pp. 178-185\}; Hölderlin, 1988 \{“Remarks on Oedipus," §3, p. 107, and "Remarks on 
Antigone," §2, p. 110\} and 1998 \{“As on a holiday...," pp. 174-175\}; and Shakespeare, 1998 \{3.2., p. 72$\}$

19. see, for example, Klossowski, 2005 \{Chapter 9\}

20. see, for example, Campana, 2003 \{“Pampa," pp. 184-185\}

21. see, for example, Foucault, 1977 \{"Nietzsche, Genealogy, History" and "Theatrum Philosophicum," pp. 139196\}-see also Dosse, 2010 \{Chapter 17, p. 320\}, and Veyne, 2010 \{Chapter 3, pp. 40-41\}

22. Ansell Pearson, 2000 \{p. 249 and p. 253\}

23. see, for example, Read, in Murphy and Mustapha, eds, 2005 \{Chapter 2, Part One: Pars Destruens-Pars Construens, pp. 30-38\}

24. Nietzsche, 1974 \{Appendix, "Songs of Prince Vogelfrei": "To Goethe," pp. 350-351\}

25. Guattari, 1995 \{Chapter 1, p. 7\}-see also Nietzsche, 1974 \{Book Four, §290, pp. 232-233\}

26. Ibid.

27. Deleuze, 1995 \{Part Three, "Michel Foucault": "Life as a Work of Art," p. 98; see also "A Portrait of Foucault," pp. 113-114 in this same part as well\}

28. Kirk, Raven, and Schofield, eds, 2003 \{Chapter VI (10), p. 203\}

29. Lucretius, 2008 \{Book Five, p. 166\}

30. see Message, in Parr, ed, 2005 [“Body Without Organs,” pp. 32-34\}

31. see Deleuze and Guattari, 1987 \{Chapter 3, p. 43\}

32. Message, in Parr, ed, 2005 [“Body Without Organs," p. 32\}

33. see, for example, Deleuze, 1990 ["Thirteenth Series of the Schizophrenic and the Little Girl," pp. 82-93\}

34. see, for example, Deleuze, 1995 \{Part Four, "Philosophy," "On Philosophy," p. 146\}

35. Deleuze, 1990 \{"Fifteenth Series of Singularities," p. 107\}-see also Deleuze, 1994 \{Chapter I, p. 41\} and 2004 \{“On Nietzsche and the Image of Thought," p. 137\}; Musil, 1999 \{Chapter 3, p. 75\} and 2001 \{pp. 137$138\}$

36. Deleuze, 1990\{Chapter Sixteen, p. 257\}

37. Nietzsche, 1971 \{\$10, To Erwin Rohde, from Basel, late-January and mid-February, 1870\}

38. Sloterdijk, 1989 \{Chapter 1, "Centauric Literature," p. 12\}

39. Musil, 1990 \{"Helpless Europe: A Digressive Journey," p. 131)

40. see, for example, Smith, 2012 \{Essay 1: "Platonism," "The Concept of the Simulacrum: Deleuze and the Overturning of Platonism," "Figures of an Inverted Platonism," pp. 19-25\}

41. see, for example, Bakhtin, 1984 \{Chapter One\}

42. see Deleuze and Guattari, 1994 \{Part One: "Philosophy," Chapter 3: "Conceptual Personae," pp. 61-83\}

43. Deleuze and Guattari, 1994 \{Part Two: "Philosophy, Science, Logic, and Art," Chapter 7: "Percept, Affect, and Concept," p. 177\}

44. Ibid.

45. Deleuze, 1995 \{Part Four, "Philosophy": "On Philosophy," p. 137\}

46. Deleuze, 1995 \{Part Four, "Philosophy": "Letter to Reda Bensamaïa, on Spinoza," pp. 164-165\}

47. Sloterdijk, 1989 \{Chapter 1, "Centauric Literature," p. 12\}

48. Deleuze, 2007 ["What is the Creative Act," p. 320\}

49. Musil, 1990 \{“The German as Symptom," p. 163\}

50. Artaud, 1982 \{To Have Done with the Judgment of God: Conclusion, p. 79\}

51. Deleuze, 1995 \{Part Four, "Philosophy": "On Philosophy," p. 146\}

52. see, for example, Deleuze, 1997 \{“The Exhausted," p. 154\} and also Blanchot, 2003 \{§15, "Musil," pp. 134$149\}$

53. Nietzsche, 1996 \{Volume I, §34, p. 30\}-see also Musil, 1990 \{“The German as Symptom,” §2, p. 168\}, and Nietzsche, 1996 \{Volume I, §254, p. 120, and Volume II, Part One: AOM, §26\}

54. Musil, 1990 [“Address at the Memorial Service for Rainier Maria Rilke in Berlin,” pp. 237-249\}

55. see, for example, Deleuze and Guattari, 1987 \{Chapter 6, pp. 159-161\}

56. Deleuze and Guattari, 1987 \{Chapter 6, pp. 153\}

57. Nietzsche, 1962 \{§6, pp. 57-58\} 
58. Nietzsche, 1974 \{Book One, §45, p. 110\}-see also Nietzsche, 1996 \{Volume II, Part Two: WS, §295, p. 385\}

59. Musil, 1995b \{From the Posthumous Papers: Part I, Chapter 52, p. 1242\}

60. Emerson, 1926 \{"First Series": Chapter I, "History," pp. 26-27\}

61. Nietzsche, 1982 \{Thus Spoke Zarathustra, Third Part, "On the Vision and the Riddle," §2, pp. 269-270\}

62. Nietzsche, 1996 \{Volume I, §251, p. 119\}

63. Deleuze, 1995 \{Part Three, "Michel Foucault": "Life as a Work of Art," p. 99\}

64. Musil \{"Sketch of What the Writer Knows" (1918), p. 64\}

65. Musil \{"Sketch of What the Writer Knows" (1918), pp. 62-63\}

66. Musil \{"Sketch of What the Writer Knows" (1918), p. 63\}

67. Musil \{"Sketch of What the Writer Knows" (1918), p. 64\}

68. Deleuze, 1995 \{Part Three, "Michel Foucault": "A Portrait of Foucault," p. 115\}

69. Sloterdijk, 2013 \{Part I, Chapter 5, "Cur Homo Artista: On the Ease of the Impossible," "Anthropotechnics: Turning the Power of Repetition Against Repetition, pp. 197-198\}

70. Nietzsche, $1967\{\S 490$, p. 270\}

71. Musil, 1999 \{§3, p. 75 (translation slightly modified)\}-see also Musil, 2001 \{pp. 155-157\}, and Nietzsche, 2000 \{Beyond Good and Evil: Part Nine: "What Is Noble," §285, p. 417\}

72. Emerson, 1926 \{"Second Series": Chapter I, "The Poet," p. 263\}

73. see, for example, Deleuze, 2006 \{Preface to the English Edition, p. x, p. xii, and p. xvi; Chapter 2, §14, pp. 68-71; Chapter 3, §14, p. 103; Chapter 4, §§11-13, p. 133-141\}

74. see, for example, Deleuze, 2006 \{Chapter 3, §4, p. 82\}

75. Nietzsche, $1962\{\S 6$, pp. 57\}

76. Nietzsche, $1962\{\S 6$, pp. 58\}

77. Ibid.

78. Ibid.

79. Nietzsche, $2003\{\S 1[58]$, p. 60\}

80. Musil \{"Sketch of What the Writer Knows" (1918), p. 64\}

81. Sloterdijk, 2013 \{Introduction: "On the Anthropotechnic Turn," "The Planet of the Practising”: Chapter 2, "Remote View of the Ascetic Planet," p. 33\}

82. Musil, 1995a \{Part II, Chapter 62, p. 273\}-see also \{Part Two, Chapter 62, p. 274\}

83. Deleuze and Guattari, 1994 \{Part One, "Philosophy": Chapter 3, "Conceptual Personae," p. 71\}-see also Poxon and Stivale, in Stivale, ed, 2005 \{Part II, Encounters: Chapter 5, "Sense, Series,"\}

84. Foucault, 1985 \{Introduction, Chapter 1, pp. 8-9\}-see also Foucault, 2003 [“The Masked Philosopher," p. 179\}

85. see Deleuze, 2006 \{Chapter 4, §11, pp. 133-135\}

86. Deleuze, 1990 \{“Fifteenth Series of Singularities," p. 107\}-see also Deleuze, 1994 \{Chapter I, p. 41\} and 2004 \{“On Nietzsche and the Image of Thought," p. 137\}; Musil, 1999 \{Chapter 3, p. 75\} and 2001 \{pp. 137$138\}$

87. see, for example, Deleuze, 2006 \{Chapter 5, §9, p. 174\}

88. see, for example, Emerson, 1926 \{“First Series": "The Over-Soul," pp. 200-201\}, and Nietzsche, 2000 \{Ecce Homo: "Thus Spoke Zarathustra," §3, pp. 756-757

89. Deleuze, 2006 \{Conclusion, p. 198\}

90. see, for example, Nietzsche, $1962\{\S 7$, pp. 62-63\}

91. Deleuze and Guattari, 1994 \{Part Two: "Philosophy, Science, Logic, and Art," Chapter 6: "Prospects and Concepts," p. 160\}

92. Hölderlin, 1988 \{“Remarks on Antigone," §2, p. 110\}

93. Nietzsche, 2000 \{On the Genealogy of Morals: Preface, §7, pp. 457-458\}

94. Sophocles, 2013 \{Oedipus the King, p. 135\} - see also Hölderlin, 1988 \{“Remarks on Oedipus,” pp. 107$108\}$

95. Deleuze, 1988b \{Chapter One, p. 3\} 
96. Nietzsche \{Book Five, §377, pp. 338-340\}

97. Nietzsche, 1974 \{Book Four, §290, pp. 232-233\}

98. Deleuze, 1995 \{Part Three: "Michel Foucault": "A Portrait of Foucault," p. 113\}

99. see, for example, Deleuze, 1988a \{Appendix: "On the Death of Man and Superman," §III, pp. 129-132\}

100. Musil, 1990 \{“Sketch of What the Writer Knows," p. 64\}

101. To my knowledge, the only references to Musil in Deleuze occur in the later writings and afford us but an incomplete taste of his recokoning with The Man Without Qualities - see Deleuze, 1997 \{"Bartleby; or the Formula," p. 74 and p. 82, and "The Exhausted," p. 154\}

102. To my knowledge, despite the apparent similarity of their discussions of essayism, there is mention of Musil in Foucault's writings.

103. see Blanchot, 2003 \{\$15, “Musil," pp. 134-149\}

104. Deleuze, 1995 \{Part Three: "Michel Foucault": "A Portrait of Foucault," p. 110\}

105. see Deleuze, 1995 PPart Four: "Michel Foucault": "Life as a Work of Art," p. 97, and "A Portrait of Foucault," pp. 110-111\}, and Foucault, in Foucault and Blanchot, 1990 \{Maurice Blanchot: The Thought from the Outside: "The Experience of the Outside," pp. 15-19\}

106. Musil, 1986 \{“The Temptation of Quiet Veronica," p. 178\}

107. Nietzsche, 1982 \{Twilight of the Idols: "Skirmishes of an Untimely Man," §49, pp. 553-554\}

108. Musil, 1990 \{"Sketch of What the Writer Knows," p. 65\}

109. Ibid.

110. Musil, 1998 \{§22, p. 427\}; see also Deleuze, 2007 \{“What is the Creative Act," p. 329\}

111. Musil, 1990 [“Address at the Memorial Service for Rilke in Berlin (1927)," p. 248\}

112. see, for example, Roy, 2004

113. Benn, 1977b \{“Epilog und lyrisches Ich,” p. 13\}-translation in Sloterdijk, 1987 \{Pr, p. xxvi\}

114. Ibid.

115. Callus and Herbrechter, in Mousley, ed, 2011 ["Humanity Without Itself: Robert Musil, Giorgio Agamben and Posthumanism," p. 146\}

116. Callus and Herbrechter, in Mousley, ed, 2011 ["Humanity Without Itself: Robert Musil, Giorgio Agamben and Posthumanism," p. 146\}

117. Callus and Herbrechter, in Mousley, ed, 2011 \{"Humanity Without Itself: Robert Musil, Giorgio Agamben and Posthumanism," p. 151\}

118. see, for example, Rilke, 1964 \{Book One, pp. 13-17\}

119. Musil, 1995a \{Part I, Chapter 2, pp. 6-8, and Chapter 10, pp. 33-35\}

120. Callus and Herbrechter, in Mousley, ed, 2011 ["Humanity Without Itself: Robert Musil, Giorgio Agamben and Posthumanism," p. 157\}

121. Deleuze, 1988a \{Appendix: "On the Death of Man and Superman," §III, p. 132\}

122. see, for example, Deleuze, 1995 \{Part Five: "Politics": "Postscript on Control Societies," pp. 177-182\}

123. see Deleuze, 1988a \{"Foldings, or the Inside of Thought (Subjectivation)," pp. 94-123\}

124. Deleuze, 1988a \{Appendix: "On the Death of Man and Superman," §III, p. 130\}

125. Deleuze, 1988a \{Appendix: "On the Death of Man and Superman," §I, pp. 124-126\}

126. Deleuze, 1988a \{Appendix: "On the Death of Man and Superman," §II, pp. 126-129\}

127. Deleuze, 1988a \{Appendix: "On the Death of Man and Superman," §II, p. 129\}

128. Deleuze, 1988a \{Appendix: "On the Death of Man and Superman," §III, pp. 131-132\}

129. Veyne, 2010 \{Chapter 3, p. 42-see also Notes, p. 158\}

130. Veyne, 2010 \{Chapter 8, p. 104-see also Notes, p. 174\}

131. see, for example, Deleuze, 1983 \{Chapter 2, pp. 39-72\} and 1988b \{Chapter Two, §III, pp. 25-29\}; Nietzsche, 2000 \{On the Genealogy of Morals: Preface, §3, pp. 452-453, and Second Essay, §11, pp. 509-512\}; and

Spinoza, 1992 \{Part IV, pp. 152-200\}

132. Leopardi, 2010 \{§XII, "Infinity," p. 107\}

133. Leopardi, 2010 \{§XII, “Infinity," p. 106\} 
134. Campana, 2003 \{“Pampas," p. 183\}

135. Campana, 2003 \{“Pampas," pp. 178-179\}

136. Spinoza, 1982 \{Part I, Proposition 34, p. 56\}

137. Spinoza, 1951 \{A Political Treatise: Chapter II, B3, pp. 291-292\}

138. see, for example, Deleuze, 1988a \{“Foldings, or the Inside of Thought (Subjectivation)," pp. 97-101\};

Deleuze, 1995 \{Part Three, "Michel Foucault": "Life as a Work of Art," p. 97, and "A Portrait of Foucault," pp. 110-111\}; and Foucault, in Foucault and Blanchot, 1990 \{Maurice Blanchot: The Thought from the Outside:

"The Experience of the Outside," pp. 15-19\}

139. Deleuze, 1988a ["Foldings, or the Inside of Thought (Subjectivation)," p. 98\}

140. Deleuze, 1990 \{“Fifteenth Series of Singularities," p. 107\}

141. Ibid.

142. Deleuze, 1994 \{Chapter I, pp. 55-57, and Chapter III, pp. 143-145\}

143. Musil, 1995a \{Part I, Chapter 82, p. 384\}

144. Deleuze and Guattari, 1987 \{Chapter 3, p. 51; Chapter 10, p. 257; Chapter 11, pp. 314-323 and p. 336\}

145. Sharp, 2011 \{Chapter Six, pp. 210-220\}

146. Sharp, 2011 \{Chapter One, p. 26\}

147. Negri, 2005 \{Time for Revolution: "Kairòs," “The Immeasurable," §2:5, p. 151\}

148. Deleuze and Guattari, $1983\{\S 1: 3$, p. 21$\}$

149. Nietzsche, 2003 \{“On Truth and Falsity in Their Extramoral Sense (1873)," §1, p. 94\}-see also Deleuze, 1994 \{Conclusion, pp. 274-276\}

150. see, for example, Hölderlin, 1988 \{“Remarks on Oedipus," §3, p. 107\}-see also Nietzsche, 1982 \{Thus Spoke Zarathustra: First Part, "Zarathustra's Prologue," § 4, p. 128; Third Part, "The Seven Seals (Or: The Yes and Amen Song)", §1, p. 340; and Fourth Part, "On the Higher Man," §7, p. 401\}

151. see, for example, Hölderlin, 1988 \{"Becoming in Dissolution," pp. 96-100\}

152. see, for example, Emerson, 1926 \{First Series: Chapter IX, "The Over-Soul," pp. 198-202\}, and Nietzsche, 2000 \{Beyond Good and Evil: "What Is Noble," §285, p. 417; and Ecce Homo: "Thus Spoke Zarathustra," 3, pp. 756-757\}

153. Musil, 1995b \{Part III, Chapter 12, p. 818\}

154. see Heraclitus, in Kirk, Raven, and Schofield, eds, 2003 \{Chapter VI, §220 (Fr 64), p. 196\}

\section{Cite this Essay}

https://doi.org/10.20415/rhiz/034.e01

RHIZOMES ISSN 1555-9998 $\star 230$ East Hall Bowling Green State University Bowling Green, OH 43403

Editors: Ellen Berry and Carol Siegel. Reviews editor: Craig J. Saper. Technical editor: Helen J Burgess 